\title{
THE INFLUENCE OF THE ROLE OF AGRICULTURAL EXTENSION OFFICERS ON THE KNOWLEDGE LEVEL OF ROBUSTA COFFEE FARMERS ABOUT FARM CARD PROGRAM IN JUMO DISTRICT TEMANGGUNG REGANCY
}

\author{
Ananda Aulia Rahman ${ }^{1)}$ Dyah Mardiningsih ${ }^{2)}$ Tutik Dalmiyatun ${ }^{2)}$ \\ ${ }^{1)}$ Program of Agribusiness, Faculty of Animal Husbandry and Agriculture Diponegoro University, Campus drh. R. \\ Soejono Koesoemowardojo, Tembalang, Semarang City. Email: anandaaulia0606@gmail.com \\ ${ }^{2)}$ Faculty of Animal Husbandry and Agriculture Universitas Diponegoro, Kampus drh. R. Soejono Koesoemowardojo, \\ Tembalang, Semarang City
}

\begin{abstract}
Farm card program is tool of redemption transaction and payment of subsidized fertilizer for farmers. This research aimed to know the role of agricultural extension officers as a communicator, motivator and facilitator on the knowledge level of robusta coffee farmers about farm card program in Jumo District Temanggung Regency, to know the knowledge level of robusta coffee farmers about farm card program and to analized the influence of the role of agricultural extension officers role on the knowledge level ofrobusta coffee farmers about farm card program in Jumo District Temanggung Regency. This research was carried out on November 2017 until Januari 2018 in Jumo District Temanggung Regency. Research method wassurvey. Data analized with descriptive analysis and linear multiple regression analysis. Results of the research showed that the role of extension officers as a communicator, motivator, facilitator were good. The knowledge level of robusta coffee farmers about farm card program were good. The role of extension officers as communicators did not affecton the knowledge level of robusta coffee farmers about the farm card program, where as the role as motivator and facilitator influenced on the knowledge level of robusta coffee farmers about farm card program. The role of agricultural extension officers as a communicator, motivator and facilitator simultaneously influence the knowledge level of robusta coffee farmers about farm card program in Jumo District Temanggung Regency.
\end{abstract}

Keywords : Knowledge level, Farm card, Robusta coffee, Role of extension officers.

\section{INTRODUCTION}

Coffee is one of the main commodities in the plantation sector in Indonesia. The role of coffee commodities for Indonesian economy is quite important, both as a source of income for coffee farmers, foreign exchange source, industrial raw materials producers, and employment providers through processing, marketing and trade (Chandra et al., 2013). The yield of agriculture and plantation contributes to the increase of state revenue. The government has a program that is still running until now one of them is the policy of subsidized fertilizer. Central Java Province is a province that creates innovation from the policy of subsidized fertilizer allocation. The form of support from Central Java provincial government on the policy is to issue a new policy related to procurement and distribution of subsidized fertilizer for farmers in Central Java (Putri, 2017).

Temanggung Regency is one of the producers of robusta coffee in Central Java province. Jumo Subdistrict is one of the 
districts in Temanggung Regency which has a plantation area of $1,640,51 \mathrm{Ha}$. The area of coffee harvest in Jumo sub district in 2015 was $606.46 \mathrm{Ha}$ and the production amount was 460,71 quintals. The area of coffee harvest in 2016 is $614.46 \mathrm{Ha}$ and the production amount was 472,71quintal (Badan Pusat Statistik, 2016). In accordance with the regulations set forth in the new policy in Central Java, Temanggung District also participates in the implementation of the farmer card program. Farmer program is implemented in January 2018. Tenuluh agriculture acts as a communicator, motivator and facilitator. Socialization is done to provide understanding and knowledge to farmers about farming cards. In accordance with the opinion of Indraningsih et al. (2011) which states that agricultural extensionists have a role as communicator, facilitator and motivator. The level of knowledge of farmers of robusta coffee on farmer card program in Kecamatan Jumo depends on extension ability in performing role as communicator, motivator and facilitator.

Based on this background, the research aimed to: 1) Know the role of agricultural extension as communicator, motivator and facilitator to the level of knowledge of farmers of robusta coffee about the farm card program in Jumo Subdistrict of Temanggung Regency; 2) To know the level of knowledge of farmers of robusta coffee on farm card program in Jumo Sub-district of Temanggung Regency; 3) To analyze the influence of agriculture extension role as communicator, motivator and facilitator to farmer knowledge level of robusta coffee about farmer card program in JumoSubdistrict of Temanggung Regency.

\section{RESEARCH METHODS}

Research Time and Place. This research was conducted in November 2017 until January 2018 in Jumo Sub-district of Temanggung Regency.

Research Method. The method used in this research was survey method, which is method used to collect information in form of opinion from a large number of people on certain topic. Information obtained from sample not from population (Hamdi and Bachruddin, 2014).

Data Collection Method. Data collection method was done by interview, that is collecting data obtained by asking directly to respondent using questioner. Observation is recording of an object which is required from related institution that related with research. Data type used were primary data and secondary data.

Sampling Method. Jumo Sub-district consists of 13 villages, but only 8 villages produce robusta coffee. From these 8 villages, there are several coffee farming groups that fulfill the active criteria, incorporated in law and belong to the agricultural extension worker. List of robusta coffee producing villages in Jumo subdistrict is as follows:

Table 1.Robusta Coffee Producing Village in Jumo Sub-district (Source: Jumo District Counseling Center, 2017).

\begin{tabular}{lccc}
\hline \hline No & Village & Number of Members & Number of Samples \\
\hline & & $---{ }^{2}$ & 5 \\
1. & Jamusan & 85 & 15 \\
2. & GunungGempol & 264 & 13 \\
3. & Giyono & 226 & 10 \\
4. & Ketitang & 188 & 8 \\
5. & Jumo & 140 & 16 \\
6. & Kertosari & 296 & 11 \\
7. & Jombor & 195 & 16 \\
8. & Gedongsari & 277 & 94 \\
\hline
\end{tabular}


The method used in determining the number of samples is Slovin method with the formula used is as follows:

$$
\mathrm{n}=\frac{\mathrm{N}}{\mathrm{N}\left(\mathrm{e}^{2}\right)+1}(\text { Sukandarrumidi, 2012) }
$$

\section{Description :}

$$
\begin{array}{ll}
\mathrm{N} & =\text { Sample Size } \\
\mathrm{N} & =\text { Population Size } \\
\mathrm{e} & =\text { Error coefficient }
\end{array}
$$

Based on calculations obtained 94 samples from 1.671 coffee farmer in Jumo District.The number of samples is divided into 8 villages with the sample taken using the proportional allocation method.

$$
\mathrm{n}_{\mathrm{i}}=\left[\frac{\mathrm{N}}{\mathrm{Ni}}\right] \mathrm{n} \ldots \ldots . . .(\text { Sugiyono, 2015) }
$$

Description :

$$
\begin{array}{ll}
\mathrm{n} & =\text { total of sampel } \\
\mathrm{N} & =\text { Population in Each Group } \\
\mathrm{n}_{\mathrm{i}} & =\text { Sample unit/afarmer } \\
\mathrm{N}_{\mathrm{i}} & =\text { total of population }
\end{array}
$$

Sampling is done by Probability Sampling method by multistage random sampling, where sampling unit is group.

Data Analysis Method . The test of this research used descriptive analysis and multiple linear regression test. Before doing multiple linear regression analysis, normality test and classical assumption test were performed.

Multiple Linear Regression Analysis. Multiple regression model is a regression model used to determine the level of influence between one dependent variable with some independent variables (Sukandar rumidi, 2012). The systematic formula is:

$\mathrm{Y}=\mathrm{a}+\mathrm{b}_{1} \mathrm{X}_{1}+\mathrm{b}_{2} \mathrm{X}_{2}+\mathrm{b}_{3} \mathrm{X}_{3}+\mathrm{e}$ (Sukandarrumidi, 2012).

Description:

$$
\begin{aligned}
\mathrm{Y} & =\begin{array}{l}
\text { Knowledge Level Farmer About } \\
\text { Farm Card (Score) }
\end{array} \\
\mathrm{X}_{1} & =\text { Communicator (score) } \\
\mathrm{X}_{2} & =\text { Motivator (score) }
\end{aligned}
$$

$$
\begin{array}{lll}
\mathrm{X}_{3}=\text { Fasilitator (score) } & \\
\mathrm{A}=\text { Constants Value } & \\
\mathrm{b}_{1}, \mathrm{~b}_{2}, \mathrm{~b}_{3} \quad= & \begin{array}{c}
\text { Regression } \\
\text { Coefficients }
\end{array} & \text { Variable } \\
\mathrm{e} \quad=\text { Error rate } &
\end{array}
$$

Hypothesis :

$\mathrm{H}_{0}$ :Allegedly there is no influence of the role of extension workers to the level of knowledge of robusta coffee farmers about the farm card program in Jumodistrict TemanggungRegency.

$\mathrm{H}_{1}$ :Allegedly there is an influence of the extensionist role on the knowledge level of robusta coffee farmers about the farm card program in Jumo district Temanggung Regency.

\section{RESULTS AND DISCUSSION}

Respondent Identity. The number of farmers in the study area showed that most of the respondents were in productive age of $95.75 \%$. Based on the primary data obtained can be seen that farmer respondents are average classified in the productive age, so the opportunity to absorb information and inovation was greater. This is in accordance with the opinion of Cahyono (2011) which stated that the productive age of a farmer is 15-65 year. Productive age physically has greater power than old age, in addition productive farmers are easier in accepting innovation.

Based on the primary data it is known that most of the respondents graduated from elementary school as many as 45 people $(47.87 \%)$. The level of someone 'seducation or knowledge can influence the way of thinking to further develop and improve agricultural yields to a better. This is in accordance with the opinion of Iqbal et al. (2014), which stated that farmers with higher education generally will more quickly master and apply the latest farming technology that exists compared to farmers whose education level is still low.

Based on the primary data it is known that the experience of farming was 
at most $>10$ years as many as 84 people $(89.36 \%)$. Farmers of respondents have an average experience of farming that has been long enough. Farming experience by farmers of respondents who have long enough to make farmers have the knowledge and skills in farming . This is in accordance with the opinion of Marliati et al. (2008) which stated that the experience of farmers with an average of $>14$ years is expected to support the success of agribusiness farmers and certainly supported by adequate formal and non formal education.
Farm Card Program. Problem in supervision, procurement and distribution of subsidized fertilizers still have constraints, among others : that has not been right target of subsidized fertilizer rights, permeation, scarcity and price increase at farm level.

The farm card program is expected to provide a solution for farmer to get fertilizer easily. The farmer card program intends to optimize the distribution of subsidized fertilizer in exactly six types, quantities, prices, quality, time and place.

Table 2. Number and Percentage of Respondents by Characteristics.

\begin{tabular}{lccc}
\hline \hline No & Respondent Identity & Number & Percentage \\
\hline & --- orang--- & $---\%---$
\end{tabular}

1. Age

- 23 - 30year old

- 31 - 40 year old

- 41 - 50 year old

- 51 - 65 year old

- 66 - 75 year old

Total

2. Education

Graduated from Elementary School

Graduated from Junior High School

Senior High School

Collage

Total

100,00

3. The Number of Familiy members

1-4 people

$>4$ people

Total

4. Farming Experience

1-10 years

$>10$ years

Total

5. Primary Livelihood

Farmer

Entrepreneur 
Table 3. The Number and Percentage of Respondents by Role of Extension Officer as Communicator.

\begin{tabular}{lrrr}
\hline \hline \multicolumn{1}{c}{ Communicator } & The Number of Respondents & \multicolumn{2}{c}{ Percentage } \\
& ------ respondent------ & \\
Not Very Good & - & \\
Not Good & - & - \\
Fair & 13 & 13.83 \\
Good & 74 & 78.72 \\
Very Good & 7 & 7.45 \\
\hline \multicolumn{1}{c}{ Total } & 94 & 100.00 \\
\hline
\end{tabular}

Purchasing subsidized fertilizer using farmer's card, ie farmer brings farmer card that has been registered by agriculture office, secondly the farmer hands over the farmer card to the officer then the officer will swipe the farm card at EDC. Thirdly the cards that have been swiped earlier, it would be valid whether the card validity or not, and the card owner whether it still has a balance or not, it can already be read through the server at BRI. Fourthly through the Indonesian Food Management Information System (SIMPI) data can be read related to the allocation of fertilizer. Fifthly, there will be allocation and data of farmers. Sixthly give fertilizer to farmers.

Communicator . Based on Table below can be seen that the role of agricultural extension as a communicator belonging to the category of Good with a percentage of $78.72 \%$ and the average score of 19.28. Good category is in the range of scores between 18 - 21. Assessment of the role of extension as a communicator based on the ability of extension in conveying information, the media used by the extension, the ability of the instructor in the language that is easy to understand and the approach taken in order to occur interactive communication.

Motivator. Based on the table below can be seen that the role of agricultural extension as a motivator belonging to the category of Good with a percentage of $68.08 \%$ and the average score of 19.23. The Good category is in the range of scores between 18 and 21.
Assessment of the role of extension officer as motivator based on the ability of extension officer to motivate farmers to develop farming, to influence farmers to follow extension activities, extension ability to make farmers interested as well as following the farm card program and farmers ability in explaining in detail the usefulness and implementation of farmer cards.

Facilitator. Based on the table below can be seen that the role of agricultural extension as a facilitator pertained Good with a percentage of $62.77 \%$ and the average score of 19.38. The Good Category is within the range of score between 18 and 21. The role assessor of the extension as a facilitator is basedon extension performance in providing routine schedule for counseling, willingness of extensionist to listen to farmer's complaint to problems faced and facilitation of farming card from socializing to how the use of farm card.

Knowledge Level. Based on the table below it can be seen that the level of knowledge of Robusta coffee farmer on the farm card program pertained Good with a percentage of $63.83 \%$ and the average score of 72.87.Category Both are in the range score between 69 - 84. Farmers knowledge level of the farm card program on the meaning of farmers' cards, benefits, technical implementation and use of the farming cards. The results of interviews with farmers showed that most farmers 
admitted to information related to the farm card program has been informed by extension workers in extension activities. Knowledge of farmer card is generally understood but to be more specific is still not understood by some farmers.

Kolmogorov - Smirnov Normality Test. Based on normality test result, it can be seen that the significance (Asym.Sig 2- tailed) obtained by communicator variable was 0.063 , motivator variable equal to 0.088 , facilitator variable equal to 0.05 and variable of knowledge level equal to 0.397 .

Multicolinearity Test. If the tolerance value is $>0.01$ and the VIF resultedis $<10$ then there is no multicol linearity. Multicol linearity test results showed that there was no multicollinearity.

Table 4.The Number and Percentage of Respondents Based by the Role of the Extension Officer as a Motivator.

\begin{tabular}{lrr}
\hline \hline \multicolumn{1}{r}{ Motivator } & The Number of Respondent & Percentage \\
& ------ Respondent------ & --- \% $^{----}$ \\
Not very good & - & - \\
Not good & - & - \\
Fair & 18 & 19.15 \\
Good & 64 & 68.08 \\
Very Good & 12 & 12.8 \\
\hline \multicolumn{1}{c}{ Total } & 94 & 100.00 \\
\hline
\end{tabular}

Table 5.The Number and Percentage of Respondents Based by the Role of the Extension Officer as a Facilitator.

\begin{tabular}{lrrr}
\hline \multicolumn{1}{r}{ Fasilitator } & JumlahResponden & Persentase \\
\hline & ------ orang ----- & $---\%$--- \\
Not very good & - & \\
Not good & - & - \\
Fair & 20 & 21.28 \\
Good & 59 & 62.77 \\
Very Good & 15 & 15.95 \\
\hline \multicolumn{1}{r}{ Total } & 94 & 100.00 \\
\hline
\end{tabular}

Table 6.Number and Percentage of Respondents by Level of Knowledge

\begin{tabular}{lrr}
\hline \hline \multicolumn{1}{c}{ Knowledge Level } & The Number of Respondents & \multicolumn{2}{c}{ Percentage } \\
\hline & ----- respondent---- & $---\%$--- \\
Not very good & - & - \\
Not good & - & - \\
Fair & 27 & 28.72 \\
Good & 60 & 63.83 \\
Very Good & 7 & 7.45 \\
\hline \multicolumn{1}{c}{ Jumlah } & 94 & 100.00 \\
\hline
\end{tabular}


Autocorrelation test. The results of auto correlation test indicated that Durbin Watson's value was 1.973 . When viewed from the Durbin Watson table then obtained the value of dUwas 1.731 and the value of $\mathrm{dL}$ was 1.5991. Then we can know the value of auto correlation between $1.731<$ $1.788<2.269$ then there was no autocorrelation.

Heteroscedasticity Test. Based on the results of Hetero scedasticity test seen that the Scatterplott graph did not form a pattern and the points spread randomly so it can be concluded that the data did not occur hetero scedasticity.

Multiple Linear Regression Analysis. Based on the Table below, it can be concluded that the result of multiple linear regression between Communicator (X1), Motivator (X2) and Facilitator (X3) on Level of Knowledge ( $\mathrm{Y}$ ) is as follows:

$\mathrm{Y}=5.582+0.516 \mathrm{X}_{1}+1.666 \mathrm{X}_{2}+1.305 \mathrm{X}_{3}$ $+\mathrm{e}$

Based on the equation of multiple linear regression analysis above obtained the result that the constant value of 5.582, the value of constant is positive value, it means if the value of the communicator variable, motivator and facilitator didn't exist or equal to 0 , then the value of the variable level of knowledge equal to 5.582. In other words, if communicators, motivators and facilitators gacve the influence then the level of knowledge will be 5.582. Coefficient of regression of variable of Communicator (X1) equal to 0.516 , it means if communicator (X1) have increase one value hence knowledge level increase as much as 0.516 assuming other independent variable was constant. The regression coefficient of Motivator (X2) variable equal to 1.666 it means that if Motivator (X2) had increased one value then knowledge level has increase equal to 1.666 with assumption that other independent variables were constant. The regression coefficient of the Facilitator (X3) variable was 1.305 . If the Facilitator (X3) experiences an increase in value, the knowledge level increased by 1.305 with the assumption that the other independent variable was constant.

The results of multiple linear regression showed that the value of coefficient of determination (RSquare) of 0.409 or $40.9 \%$. The value indicatedthat the role of extension worker including Communicator (X1), Motivator (X2) and Facilitator (X3) influenced the knowledge level of farmer equal to $40.9 \%$ while the rest equal to $59.1 \%$ level of farmer knowledge influenced by other variable was not examined in this research.

t-Test (Parsial). Based on the results . it is known that the t-count value of Communicator (X1) variable was 1.274, Motivator (X2) was 4.279 and Facilitator (X3) was 3.753.t value of Motivator (X2) and Facilitator (X3)>t Table was equal to 1.986 ( Appendix 7), then H0 was rejected and it is concluded that partially Motivator and Facilitator variables affect the Knowledge Level (Y), while the value of $t$ count variable Communicator (X1) of 1.274 $<\mathrm{t}$ Table was equal to 1.986 then H0 accepted and concluded that partially not affect the Knowledge Level (Y).

Table7.Hasil Analisis Regresi Linear Berganda.

\begin{tabular}{crrrrr}
\hline \hline Model & \multicolumn{2}{c}{ Unstandardized Coefficients } & \multicolumn{1}{l}{ T } & \multicolumn{1}{l}{ Sig. } & Adjusted R Square \\
\cline { 2 - 3 } & \multicolumn{1}{c}{$\mathrm{B}$} & & & & \\
\hline (Constant) & 5.582 & 9.309 & .600 & .550 & .409 \\
$\mathrm{X}_{1}$ & .516 & .405 & .1 .274 & .206 & \\
$\mathrm{X}_{2}$ & 1.666 & .389 & 4.279 & .000 & \\
$\mathrm{X}_{3}$ & 1.305 & .348 & 3.753 & .000 & \\
\hline
\end{tabular}


f-Test (Simultaneously). Based on the results if the data at the level of significance is 5\% known that the f-value was 22.445 with a significance value of 0.000 . Hypothesistesting simultaneously obtained the value of $\mathrm{F}$ arithmetic of 22.445> F Table of 2.71.dan significance value 0,000 $<0.05$ then $\mathrm{H} 0$ was rejected and it can be concluded that the variables of Communicator (X1), Motivator (X2) and Facilitator (X3) influence simultaneously on Knowledge Level (Y).

\section{CONCLUSION AND SUGGESTION}

\section{Conclusion.}

Based on the results and the discussion can be summarized as follows: 1) The role of agricultural extension officer as communicator, motivator and facilitator belonging in the category of Good in improving knowledge of robusta coffee farmer to the farm card in District Jumo Temanggung Regency; 2) The level of knowledge of robusta coffee farmer on farm card program is categorized as good because most farmers of robusta coffee have understood about the farm card program; 3) The role of agricultural extension officer as communicators does not affect the level of knowledge of robusta coffee farmers to farmcard program, while the role of extension as a motivator and facilitator affect the level of knowledge of robusta coffee farmers on the farm card program. The role of agricultural extension officer as communicators, motivators and facilitators simultaneously affect the level of knowledge of robusta coffee farmer to the farm card program in Jumo District, Temanggung.

\section{Suggestion.}

Extension officershould be more active in providing up-to-date information on farming planning and technical implementation of agricultural innovation, processing and marketing of coffee as market competition that is always increasing, so that farmers are more competitive in the market and do not survive in comfort zones; 2) Farmers should be more active follow the extension activities conducted by extension officer in order to improve farmers knowledge and insight about government programs such as peasant card program and other programs; 3) The next researcher needs to master the situation and condition of JumoDistrict so as not to obstruct the research process, whether in terms of culture or language so that communication with farmers can be smooth and clear and prepare good physical condition because climate in the area is quite extreme and often change.

\section{REFERENCES}

Badan Pusat Statistika. 2016. Kecamatan Jumo dalam Angka. Badan Pusat Statistika Kabupaten Temanggung, Temanggung.

Cahyono, S. A. 2011. Faktor-faktor yang mempengaruhi petani menyadap pinus di kawasan hutan dengan tujuan khusus (KHDTK) Gombong.J. Tekno Hutan Tanaman. $4(2): 1-8$.

Chandra, D., H. Ismono. dan E. Kasymir. 2013. Prospek Perdagangan Kopi Robusta Indonesia di Pasar Internasional. J. IIA. 1 (1) : 1-6.

Hamdi, A. S .dan E. Bahruddin.2014. Metode Penelitian Kuantitatif Aplikasi dalam Pendidikan. Deepublish, Yogyakarta.

Indraningsih, K. S., B. G. Sugihen., P. Tjitropranoto., P. S. Asngari. dan H. Wijayanto. 2011. Kinerja Penyuluh Dari Perspektif Petani dan Eksistensi Penyuluh Swadaya sebagai Pendamping Penyuluh Pertanian. J. Analisis Kebijakan Pertanian. 8 (4) : $1-19.1$ 
Iqbal, A. M., D. A. H. Lestari. dan A. Soelaiman. 2014. Pendapatan dan Kesejahteraan Rumah Tangga Petani Ubi Kayu di Kecamatan Suka dan Kabupaten Lampung Timur. J. IIIA. 2 (3) : 1-7.

Marliati,.Sumardjo,. P. S. Asngari., P Tjitropanoto. dan A. Saefuddin. 2008. Faktor-faktor Penentu Peningkatan Kinerja Penyuluh Pertanian dalam Memberdayakan Petani (Kasus di Kabupaten Kampar). J. Penyuluhan. 4 (2) : 1-8.

Putri, N. 2017. Proses Komunikasi Penyuluhan Balai Penyuluhan Pertanian Kecamatan Giriwoyo Kabupaten Wonogiri untuk Mensosialisasikan Program Kartu Tani.J.Penyuluhan.2 (3) : 1-18.

Sugiyono. 2015. Metode Penelitian Kuantitatif, Kualitatif dan $R \&$ D. Alfabeta, Bandung.

Sukandarrumidi.2012. Metode Penelitian Petunjuk Praktis untuk Peneliti Pemula. Gadjah Mada Press, Yogyakarta. 